\title{
Snowball Earth is dead! Long live Snowball Earth!
}

\author{
Institut für Geologie und Paläontologie, Westfälische-Wilhelms Universität, Correnstr. 24, 48149 Münster, Germany (gshields@uni-muenster.de)
}

Ticino in southern Switzerland played host this summer to a most extraordinary meeting of minds. About eighty scientists from all over the world came together in the exquisite setting of Monte Verita to discuss possibly the coldest spell in our planet's long history: the Cryogenian Period. 'Snowball Earth 2006' was organized by a research group at the ETH in Zurich under the leadership of Professor Philip Allen, now at Imperial College, London, and was the first conference to focus solely on this topic. The Cryogenian global freeze of about 720-635 million years ago closely preceded-some would say ominously so-the first fossil evidence for animal life on Earth, and as such has attracted the attention of natural scientists worldwide. Such a resurgence of interest in deep Earth history has not been witnessed since the great $\mathrm{K} / \mathrm{T}$ boundary debate of the early 1980s. On the first day of the conference, on a hot and sultry evening during the hottest July on record, it was ice of a different kind that was being broken high above Lago Maggiore. The first hesitant introductions over chilled white wine made it clear that a truly multidisciplinary throng had been invited for what promised to be a vigorous debate on the causes and effects of Neoproterozoic climate change. Gathered for the 'snowball fight' were geologists, palaeobiologists, geochemists, geophysicists and climate modellers, all of whom would, oneby-one over the coming five days, borrow centre stage to offer their unique perspective on this most polarizing of topics.

Despite an earlier pedigree (Kirschvink, 1992), it was only after 1998 that the Snowball Earth hypothesis really took off with the publication in Science of an article by Paul Hoffman and colleagues from Harvard University (Hoffman et al., 1998). The possibility that an ice cover might ever have been truly global caught the imagination of scientists worldwide. Large research projects were soon launched in USA, France, Germany, Japan and China as well as an International Geoscience Project (www.IGCP512.com) that currently boasts over two hundred participants from thirty different countries around the world. IGCP 512 helped to sponsor several speakers' participation at the meeting as well as an earlier, highly successful field excursion to the key Cryogenian and Ediacaran deposits of South China (organised by Zhu Maoyan, Xiao Shuhai and Yin Chongyu). Quite why the idea triggered so much attention after this latest resurrection owes no small debt to the tireless advocacy of Paul Hoffman who has travelled the world researching and debating his own preferred scenario, commonly referred to as the 'Snowball Earth Hypothesis'. Over the past eight years Hoffman, his students, colleagues, and others, many of whom were present at the meeting, have tinkered with the hypothesis, causing it to transmogrify as new data quickly followed old (e.g. Hoffman and Schrag, 2002). So much so that Philip Allen informed us rather surprisingly on the first day that he was still unsure just what the Snowball Earth Hypothesis was, or whether its constant evolution meant that it could even be tested. It was his hope, and ours, that such important questions would be answered in the coming days.

The original hypothesis of Hoffman and colleagues envisaged a global ocean frozen over for periods of 15 million years or more, a water cycle that had ceased to function, ice-free continents that had long since ablated their snow cover into the low-lying ocean basins, and a planet rendered virtually barren of all biological productivity. Deliverance was painfully slow, arriving eventually in the form of millions of years of accumulated carbon dioxide from volcanic outgassing. Due to the extremely cold climate even at low latitudes, excess $\mathrm{CO}_{2}$ could not be sequestered by chemical weathering as would normally be the case (Walker et al., 1981). Once the greenhouse effect became strong enough, however, and ice at the equator could start to melt, the end came swiftly as acid rain and soaring temperatures supposedly melted the entire snowball in just a few thousand years. One of the more novel aspects of the 1998 Snowball Earth Hypothesis focused on an enigmatic carbonate rock unit that drapes glacially derived sediments of Neoproterozoic age. The carbonate alkalinity necessary to form this aptly named 'cap carbonate' was considered by the SEH to derive from the vast quantity of $\mathrm{CO}_{2}$ that had built up in the atmosphere. Upon deglaciation, this excess $\mathrm{CO}_{2}$ was rapidly removed by the hugely increased rates of silicate weathering. Or at least that was how the story went in 1998. For me and many others, one of the main aims of the Swiss meeting was to see how well this 'hard snowball' had stood the test of time. And Monte Verita, being the mountain of truth in Italian, was clearly a good place for an honest assessment.

The results of the climate modellers were sobering. There was widespread agreement that once the planet was plunged into Snowball Earth conditions, it would be remarkably difficult to get out again (e.g. Pierrehumbert, 2005). Yes, greenhouse gas concentrations would indeed rise once chemical weathering ceased; however, it would be the changing albedo of the ice cover that would determine just when the snowball melted. $\mathrm{CO}_{2}$, we were told, would probably not have been enough even at concentrations over 500 times those of today-levels that would have taken over twenty million years to reach. That the $\mathrm{CO}_{2}$ level could have risen so high was put in serious doubt by a research group from France, in particular. According to Guillaume Le Hir and colleagues from Gif-sur-Yvette, open exchange would have taken place between the atmosphere and underlying liquid ocean even if only a relatively tiny area of the surface ocean, only about the area of all the Swiss lakes combined, remained ice-free during the glaciation (Le Hir et al., 2006). This almost certainly means that a large proportion of any outgassed volcanic $\mathrm{CO}_{2}$ would have ended up in the ocean, not in the atmosphere. As a direct effect of this exchange both the acidity and the carbonate alkalinity (carbonate ion concentration) of the synglacial ocean would have increased. As soon as saturation with respect to calcium carbonate could be reestablished, then submarine weathering of volcanic silicates on the seafloor would have acted as a major sink for further injections of greenhouse gas. Le Hir and colleagues estimate that atmospheric $\mathrm{CO}_{2}$ levels would stabilize after 12 million years at levels far too low to end the Snowball Earth.

In the open-exchange scenario, a carbonate-rich ocean would result from diminished weathering rates, regardless of whether these were caused by a hard or a soft snowball, sometimes referred to as a 'slushball', around 635 million years ago. This is intriguing because elevated carbonate alkalinity is of course a prerequisite for one of the most characteristic, and still one of the most controversial features of the 1998 Snowball Earth Hypothesis: the cap carbonates. However, much has changed since cap carbonates were first proposed as the sedimentary evidence for massively high $\mathrm{CO}_{2}$ levels. On a positive note, cap carbonates are now widely acknowledged to be a global feature of the post-glacial world of 635 million years ago. One such horizon in Australia was even chosen in 2004 to define the base of the Ediacaran Period of Earth history (Knoll et al., 2004). On the downside though, theories of cap carbonate formation still abound. In particular, there is no agreement on whether the carbonate alkalinity required for their formation accumulated rapidly during deglaciation, as had been initially assumed, or whether it had been there all along, as is increasingly being proposed by a number of authors. In other words, do the cap carbonates represent the expression in the rock record of a carbonate-rich, synglacial ocean as Le Hir's analysis suggests?

If carbonate alkalinity was already in overabundance during deglaciation, just ready to precipitate out in the warmer, more produc- 
tive post-glacial world, then why are the cap carbonates so uniformly distributed around the world? Part of the reason may relate, as was suggested during the conference by at least two presenters (Martin Kennedy of University of California at Riverside and Paul Gammon of Carleton University, Ottawa), to the shutting off of terrestrial sedimentary input. Such condensed, carbonate-rich horizons would be expected to accompany any huge rise in sea level and would arguably be inevitable after something as major as the Snowball Earth deglaciation. Another explanation has also been suggested, namely that the oceans were physically stratified during cap carbonate deposition due to the influx of massive amounts of buoyant meltwater. The subsequent shutdown of upwelling would have served to homogenize the upper layers of the oceans for as long as stratification could be maintained. Paul Hoffman estimated for the benefit of the conference that the resultant pycnocline would have been up to 1,250 metres deep, far deeper even than storm waves or other normal surface mixing processes can penetrate. This would have led to the formation of an anoxic intermediate layer caused by the decay of falling organic matter. It is currently unknown how long such a 'plumeworld' (Shields, 2005) might last but I am sure that the modellers will begin to address this question in earnest before too long. Which idea, if any, may turn out to be correct depends partly on knowing how long cap carbonate deposition lasted. On this latter point, the participants could all agree that there was no agreement.

Nevertheless, strides in this direction are being made. One of the marvellous aspects of the Snowball Earth Hypothesis has been its ability to stimulate new avenues of research in a whole range of fields. During the Congress two talks presented genuinely new advances in the fields of geochemistry and geophysics. Simone Kasemann (University of Edinburgh) and Tim Raub (Yale University) both presented data that were convincing in their reproducibility, yet few previously had even suspected the possibility of such studies. Kasemann, for example, has managed to reproduce boron isotope trends (Kasemann et al., 2005) in cap carbonates from different parts of Namibia. However, the boron isotope ratio has long been assumed to be meaningless because it should be so easily altered after deposition. So what do the boron data tell us? Fluctuations in the boron isotope composition of carbonates ought to reflect changes in ocean $\mathrm{pH}$, and so, taken at face value it would appear that the world's oceans became significantly more acidic during cap carbonate deposition. Although Kasemann initially interpreted these data within the context of the extremely high $\mathrm{pCO}_{2}$ of a Snowball Earth, $\mathrm{Li}$ Hir's analysis seems to make this less plausible. A huge injection of freshwater during cap carbonate deposition would also have the same effect, and be more easily reversible, perhaps lending even more credence to the notion that the snowball melted in spectacular fashion.

And what of the new geophysics data? In what will undoubtedly become a seminal piece of work, Raub and colleagues have managed to extract polar wander trends of unprecedented high resolution (Raub and Evans, 2006). Again data can be reproduced from section to section, this time between Australian successions, while the frequency of magnetic reversals can be used to estimate sedimentation rates. Their data imply that glaciers were at tropical latitudes in Australia for at least hundreds of thousands of years. Surprisingly, the presence of magnetic reversals within the cap carbonate also indicate a prolonged duration for cap carbonate deposition of greater than 10,000 years and perhaps even as long as 100,000 years. One of the problems with this study lies in its sheer novelty. The resolution obtained by Raub and Co. is so high that there is almost nothing to compare it with from the more recent rock record. More precise age constraints on cap carbonate deposition will have to await more study.

Eight years and five days on from the 1998 rebirth of the Snowball Earth concept, are we any wiser, and not just more confused? Well, despite admitted uncertainties, I think we have come a long way. After years of fierce debate, Monte Verita was almost an anticlimax of muted, even grudging agreement on some issues. Since 1998, more and more evidence has been amassed to show that low-altitude glaciers did indeed reach tropical latitudes at least once about 635 million years ago. However, it is still unclear whether glaciers truly reached the equator. That remarkable glacial advance was preceded it appears now by a long period of globally cool climate that lasted at least 80 million years and was punctuated by at least one significant interval of warmer conditions. Although originally assumed to have lasted considerably longer than the glaciations themselves, recent age data (Kendall et al., 2006) from Australian drill core profiles, presented by Robert Creaser of the University of Alberta, seem to indicate a much reduced 'interglacial' warm spell of no more than 10 million years. Therefore, the sustained freeze between 720 and 635 million years truly earns its title of the 'Cryogenian Period' in Earth history.

Although the Cryogenian Period is not so well known as the already ratified Ediacaran Period, and fossil assemblages are notoriously depauperate (Grey, 2005), recent studies have shown that it may hold some of the secrets to the origins of animal life on Earth. The latest data from the molecular biology fraternity, namely the recently published work of Kevin Peterson of Dartmouth College (Peterson, 2005), suggests that sponges, the simplest of animal-grade organisms, originated and split from their cousins the cnidaria during the 'big freeze'. These data and the admittedly spotty fossil record both imply that the Cryogenian glaciations represented an opportunity for evolutionary diversification, which our ancestors were pleased to grasp.

Monte Verita has certainly shed more light on the truth behind our prehistory, while helping to assess the Snowball Earth Hypothesis in some detail. Has it fared well? Yes and No. While many aspects of the specific hypothesis of 1998 are being abandoned or reshaped, the strength of this unparalleled metaphor for global icehouse conditions lives on. Snowball Earth is dead! Long live Snowball Earth!

\section{References}

Grey, K., 2005, Ediacaran palynology of Australia: Memoirs of the Association of Australasian Palaeontologists, v. 31, pp. 1-439.

Hoffman, P. F., Kaufman, A. H., Halverson, G. P., and Schrag, D. P., 1998, A Neoproterozoic snowball Earth: Science, v. 281, pp. 1342-1346.

Hoffman, P. H., and Schrag, D. P., 2002, The Snowball Earth hypothesis: testing the limits of global change: Terra Nova, v. 14, pp. 129-155.

Kasemann, S., Hawkesworth, C., Prave, A., Fallick, A., and Pearson, P. 2005. Boron and calcium isotope composition in Neoproterozoic carbonate rocks from Namibia: evidence for extreme environmental change: Earth and Planetary Sciences Letters, v. 231, pp. 73-86.

Kendall, B., Creaser, R. A., and Selby, D., 2006, Re-Os geochronology of postglacial black shales in Australia: Constraints on the timin of "Sturtian" glaciation: Geology, v. 34, pp. 729-732.

Kirschvink, J. L., 1992, Late Proterozoic low-latitude global glaciation: the snowball Earth, in Schopf, J. W., and Klein, C., eds, The Proterozoic biosphere: A multidisciplinary study: Cambridge, Cambridge University Press, pp. 51-52.

Knoll, A. H., Walter, M. R., Narbonne, G. M., and Christie-Blick, N., 2004, A new period for the geologic time scale: Science, v. 305, pp. 621-622.

Le Hir, G., Godderis, Y., Donnadieu, Y., Fluteau, F., and Ramstein, G., 2006, A new scenario for Neoproterozoic snowball, in Etienne, J. L., Allen, P., Le Guerroue, E., and Rieu, R., eds., Snowball Earth 2006: Zürich, ETH Zürich, p. 63.

Peterson, K., and Butterfield, N., 2005, Origin of the Eumetazoa: Testing ecological predictions of molecular clocks against the Proterozoic fossil record: Proceedings of the National Academy of Sciences, v. 102, pp. 9547-9552.

Pierrehumbert, R., 2005, Climate dynamics of a hard snowball Earth: Journal of Geophysical Research, v. 110, D01111, 10.1029/2004JD005162.

Raub, T. D., and Evans, D. A. D., 2006, Prolonged deglaciation of Marinoan snowball Earth from an integrative Australian perspective, in Etienne, J. L., Allen, P., Le Guerroue, E., and Rieu, R., eds., Snowball Earth 2006: Zürich, ETH Zürich, pp. 89-90.

Shields, G. A., 2005, Neoproterozoic cap carbonates: a critical appraisal of existing models and the plumeworld hypothesis: Terra Nova, v. 17, pp. 299-310.

Walker, J. C. G., Hays, P. B., and Kasting, J. F., 1981, A negative feedback mechanism for the long-term stabilization of Earth's surface temperature: Journal of Geophysical Research, v. 86, pp. 9776-9782. 